\title{
Transformation of Belarus and Russian agricultural settlement system in the new economic conditions (post-Soviet period)
}

\author{
Elena Shcherbina ${ }^{1}$, Elena Gorbenkova ${ }^{2, *}$ \\ ${ }^{1}$ Moscow State University of Civil Engineering, Architecture and Urban Planning Department, \\ 129337, 26, Yaroslavskoye Shosse, Moscow, Russia \\ ${ }^{2}$ Belarusian-Russian University, Highways Department, 212000, 43, Prospect Mira, Mogilev, Belarus
}

\begin{abstract}
The transition to new economic relations in 1990, the collapse of the Soviet Union, the formation of new states caused the processes of transformation of the settlement system. That determined the need to analyse the current situation at this stage of development. The greatest changes in the structure has undergone a rural settlement that has identified the need for research in Belarus and Russia, including the justification for the new approaches to assessing the level of development of rural settlements in the structure of the current scheme of administrative divisions. Today both in Russia and in Belarus adopted a system of local government areas of rural settlements, which are included in the municipal districts that are component territorial units of federal subjects. However, the system of rural settlement of these republics have differences, which occurred because of the transformation, due to historical processes, economic and political conditions the existing States. The demographic situation in these countries is characterizing by population decline. In Russia, among federal districts the greatest population losses typical for the Far East - 6\%, Siberia - 4\%, and for the Volga Federal District - 4\%. That is, in absolute terms, respectively, $0.4 ; 0.8$ and 1.2 million people.
\end{abstract}

\section{Socialist theory of the USSR settlement system}

The collapse of the Soviet Union was the beginning of building a new settlement in the former republics, which was caused by the transition to new economic relations and a paradigm shift (a theoretical concept) of the theory of "socialist" settlement covering all territorial levels (Federal, regional, local) and all functional elements (work, recreation, everyday life) of the resettlement process and emerging as a result of its implementation of the rural network.

In the USSR the regulations system was developed (construction norms and rules SNIP, sanitary rules SanPiN), which have been used in urban design and regional planning. The methodological basis of this paradigm is the "method of employment balance", according to which were defined perspectives of development of individual settlements, and in the

* Corresponding author: gorbenkowa@yandex.ru 
aggregate, and the whole structure of long-term settlement, depending on the development scheme and a placement of industry objects and productions.

The main forming elements of the country's support framework in the territorial and settlement structure of the USSR were large (100-250 and even 500 thousand people) and the largest cities. Companies of a military-industrial complex performed a city-forming function in smaller settlements. The voluntaristic approach was present in the development of regional planning schemes of rural areas in the system of rural settlement. It was basing on a private paradigm theory of "promising" and "unpromising" residential areas. According to this theory, the existing settlements were divided into promising to be coarsening and improvement, and the unpromising to be gradual elimination as housing fund depreciation. The existing standards forbidden for capital construction in the unpromising settlements. This paradigm was basing on the collective farming concept, the development of collective and state farms (1960). The result of this policy was reduction the number of villages and rural population $[1,2]$.

In the Soviet period, the settlement system formation based on the principle of creating a reference settlement frame, which is based on interconnection of two coupled trends - the centripetal (the development of large cities and urban agglomerations) and linear-swift (the development of a country's transport system). This identified the various forms of a spatial territories organization; the three major ones are wireframe, linear, agglomeration (Figure 1). In fact, these structural forms are typical for many countries and determine a current spatial organization trends.
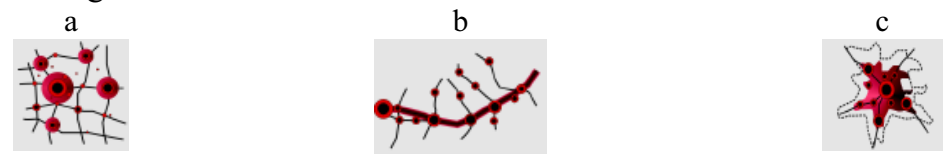

Fig. 1. The forms of a spatial organization of a settlement system: a - wireframe, b - linear, c agglomeration.

The development of one or another form caused by a multitude of factors. Natural environment as well as spatial and historical processes of settlement Russian territory had the greatest impact on the character of rural settlement system. This is typical for the development of a rural settlement system formed under the influence of soil and climatic conditions, as well as historical labour population skills. That led to the non-uniformity of a rural settlement in the territory.

The simple principle was determined to form another settlement paradigm. «People go where a favorable environment not only provides a comfortable accommodation, but also allows to realize their potential as individuals as well as citizens responsible for their own destiny and a worthy public status of towns and villages» [3]. It is this approach best meets the requirements of an innovative model of economic development, where the main resource - human capital with high intellectual potential.

\section{Features of the current Belarusian settlement system}

The highest intensity of urbanization processes (compared to other republics of the former USSR) was one of the main features of of the BSSR (Byelorussian Soviet Socialist Republic) (Table 1 [3]). That had a significant influence on the settlement structure.

Table 1. Belarusian population dynamics.

\begin{tabular}{|c|c|c|}
\hline $\begin{array}{c}\text { The area's } \\
\text { name }\end{array}$ & $\begin{array}{c}\text { Population size (thous. persons) } \\
\text { * urban population are above the line, }\end{array}$ & $\begin{array}{c}\text { The proportion of } \\
\text { urban/rural population, } \%\end{array}$ \\
\hline
\end{tabular}




\begin{tabular}{|c|c|c|c|c|c|c|c|c|c|}
\hline & \multicolumn{7}{|c|}{ rural population are below the line } & \multicolumn{2}{|c|}{} \\
\cline { 2 - 9 } & $\mathbf{1 9 7 9}$ & $\mathbf{1 9 8 9}$ & $\mathbf{2 0 0 9}$ & $\mathbf{2 0 1 5}$ & $\mathbf{1 9 7 9}$ & $\mathbf{1 9 8 9}$ & $\mathbf{2 0 0 9}$ & $\mathbf{2 0 1 5}$ \\
\hline Brestskaya & 177 & 258 & $\frac{1404.5^{*}}{491.9}$ & $\frac{1388.9}{425.4}$ & 45 & 57 & $\frac{65}{35}$ & $\frac{69.4}{30.6}$ \\
\hline Vitebskkaya & 297 & 350 & $\frac{1237.5}{341.1}$ & $\frac{1198.5}{283.1}$ & 56 & 64 & $\frac{72.4}{27.6}$ & $\frac{76.4}{23.6}$ \\
\hline Gomelskaya & 383 & 500 & $\frac{1443.2}{397.8}$ & $\frac{1424.0}{336.9}$ & 52 & 64 & $\frac{72.4}{27.6}$ & $\frac{76.4}{23.6}$ \\
\hline Grodnenskaya & 195 & 270 & $\frac{1076.7}{341.8}$ & $\frac{1052.6}{287.0}$ & 43 & 56 & $\frac{68.3}{31.7}$ & $\frac{72.8}{27.2}$ \\
\hline Minskaya & 1262 & 1589 & $\frac{1431.1}{642.1}$ & $\frac{1407.9}{608.1}$ & 53 & 64 & $\frac{55}{45}$ & $\frac{56.6}{43.4}$ \\
\hline Minsk & & & $\frac{1814.3}{-}$ & $\frac{1938.2}{-}$ & & & & \\
\hline Mogilevskaya & 290 & 356 & $\frac{1106.3}{271.5}$ & $\frac{1070.8}{224.4}$ & 34 & 43 & $\frac{75.5}{24.5}$ & $\frac{79.1}{20.9}$ \\
\hline Total & & & $\frac{9513.6}{2486.5}$ & $\frac{9480.9}{2155.9}$ & & & $\underline{73.9}$ & $\underline{77.3}$ \\
\hline
\end{tabular}

Currently, Belarus settlement system represented by three levels, which based on the existing administrative and territorial structure and conditions of transport accessibility of cities - centres of various hierarchical rank: Republican (national); Regional; Local (Figure 1) [4]. Each level corresponds to its own settlement system.

The basis of Belarus territorial at the national level was the functional zoning principle, which allows to allocate the following areas: urbanized (23\%); agricultural $(31 \%)$; environmental and recreation (34\%); special (12\%).

Agricultural areas are characterizing by a predominance of agricultural and forestry purposes lands. They based on medium and small urban settlements and including agrotowns and other rural settlements, territories of various functional use. The main resource of rural areas economic development are the earth and its resources; the leading functions are in production and processing of commercial agricultural and forestry products.

Local settlement system based on existing administrative regions, and including urban and rural settlements at the head of the town-centre, which function performed by the centre of an administrative district [4].

The basis of the rural settlement formed a group of rural settlements united to each other and with the urban settlements - the district centre in a single system, using the administrative, organizational, economic, socio-cultural and communication connections. Rural settlements are classifying according to their role in the system of settlement and population (Table 2).

Table 2. The classification of rural settlements in Belarus.

\begin{tabular}{|c|c|}
\hline \multicolumn{2}{|c|}{ The rural settlements types } \\
\hline role in the settlement system & the number of population (people) \\
\hline Reliance local centers (agro-towns) & large - over 1000 \\
\cline { 2 - 2 } & big - from 500 to 1000 \\
\cline { 2 - 2 } & medium - from 100 to 500 \\
\hline Ordinary rural settlements & large - over 1000 \\
\cline { 2 - 2 } & big - from 500 to 1000 \\
\cline { 2 - 2 } & medium - from 100 to 500 \\
\cline { 2 - 2 } & small - to 100 \\
\hline
\end{tabular}

The existing network of rural settlements of the republic preserves finely dispersed structure due to historical and natural features. Thus, the greatest number of small villages (with a population up to 100 people) are in the north (Vitebsk region), where they account 
for 83 per cent of rural settlements. The largest rural settlements are in Brest and Gomel regions. The settlements proportion with a population between 200 and 1000 is $36 \%$ in Brest region and $31 \%$ in Gomel region. That caused by natural conditions influencing the agricultural activity.

The rural settlement centres of Belarus are agro-towns - comfortable rural settlements, administrative, organizational and economic, social and cultural centres that have established production and social infrastructure to ensure social standards to agro-town's population and surrounding areas residents within a radius of 15 kilometres [5]. Such a scheme is optimal for a rural settlement. That reduces the services radius to the public social infrastructure facilities, as well as providing higher living standards to rural population. It seems that this will create a basis for improving the demographic situation.

Nowadays agro-towns are supporting settlement points, the number is 1449 settlements, and they are evenly distributing across the regions of the country.

It seems that the agro-towns sustainable development has to promoting the rural settlement optimization, formatting the profitable agricultural production, improving the infrastructure of rural settlements, increasing the cultural and o rural population living standards, creating the preconditions for demographic situation improvement, and enhancing the prestige of living in rural areas. Therefore, it is necessary to evaluate agrotowns/villages development level for the sustainable development of Belarus rural areas.

However, despite the measures taken at the national level (Program of sustainable development of rural areas) there is a rural population decrease, in addition to which the network polarization processes of settlements is occur. On the one hand, the share of medium-sized settlements, passing into the small decreases, on the other - there is a concentration of the remaining population in a few large settlements (usually in agrotowns).

Thus, we can identify the main elements in the core network of Belarus rural settlement - agricultural towns - as local centers of rural councils (governing bodies) and agricultural organizations. The basis for their further development should be a build-up of the socioeconomic potential.

\section{Features of the current Russian settlement system}

In the post-Soviet period, there have been significant changes in the structure of a rural settlement, which is associated with the authority transfer to the formation of spatial development plans to local authorities, according to the Law «On local self-government». Today, Russia has adopted a two-tier system of local self-government. The first level includes the urban and municipal districts; the second level - the urban and rural settlements, included in the municipal districts.

This led to the transformation and disorganization throughout the settlement system; in this case, there was an asymmetry in the living standard of urban and rural areas [6]. In addition, the outflow residents from the sparsely populated rural settlements into a larger brought to the widening of the largest settlements and crushing the rest, especially the smallest ones.

Implementation of the principles of local self-government and provisions of the Town Planning Code of the Russian Federation faced a number of difficulties preventing sustainable development. The uneven economic development of the regions, metropolitan regions, urban and rural settlements identified modern direction of a control system, which based on the administrative allocation of "promising" and "unpromising" villages, as well as in Soviet times. Today there is a trend of disappearance of rural settlements and municipal areas that converting to urban districts. 
The crisis of rural areas adversely affected the small towns - undermined the economic basis from the. The dynamics of Russia population in the period from 1979 to 2015 in relative terms shows that the rural population share in relation to the urban remains unchanged. But the absolute values show the rural population decrease of 3.5 million in 1979 compared to 1989 (the collapse of the USSR), and 1.0 million people to 2015, i.e. less rapid decline in the rural population, both in Belarus (Table 3). This is due to initially higher urbanization level and migrants influx.

Table 3. Dynamics of a Russian population in the period from $1979-2015$.

\begin{tabular}{|c|c|c|c|c|c|}
\hline \multirow{2}{*}{ Year } & \multirow{2}{*}{$\begin{array}{c}\text { Total population, } \\
\text { million people }\end{array}$} & \multicolumn{2}{|c|}{ Including those } & \multicolumn{2}{c|}{ In the total population, \% } \\
\cline { 3 - 6 } & 137.4 & urban & rural & urban & rural \\
\hline 1979 & 147.0 & 108.0 & 42.5 & 69 & 31 \\
\hline 1989 & 142.7 & 104.9 & 37.0 & 73 & 27 \\
\hline 2009 & 146.3 & 108.3 & 38.0 & 74 & 26 \\
\hline 2015 & & &
\end{tabular}

The existing system of Russian settlement has its own specifics. On the one hand, about $74 \%$ of the population is concentrated in urban areas; on the other hand, the area occupied by cities is only $5 \%$ of the country. Rural settlements divided into groups according to the population (Table 4 ).

Table 4. The rural areas classification by population.

\begin{tabular}{|c|c|}
\hline \multirow{2}{*}{ Groups } & Population, thousand people \\
\cline { 2 - 2 } Large & Rural settlements \\
\hline Big & $\begin{array}{c}\text { over } 5 \\
\text { from } 3 \text { to } 5\end{array}$ \\
\hline Medium & from 1 to 3 \\
\hline Small & from 0.2 to 1 \\
\hline
\end{tabular}

A distinctive feature of the Russian settlement system is the presence of different natural and geographic zones. Therefore, Russia characterized by unevenness of rural settlement in the territory: the largest concentration falls on a favorable for living and farming regions.

The population concentration in a few large settlements led to the settlement landscape polarization: increasing the share of the smallest and large settlements, while reducing the number and the share of medium. Thus, the rural settlement system characterized by a high depopulation level of the rural population; polarized areas, formed under the influence of processes of center-periphery development model; unemployment; low incomes, as well as other problems [7].

Reforms related to the liquidation of "collective-state farm system", contributed to the reduction process of small rural settlements and the increase in the rural population concentration in large settlements. These reforms were initially focusing to the cost optimization in the social sphere - the elimination of inefficient social facilities. All this has led to a violation of the ratio of the density and rural settlements size and the further polarization progress of the rural settlement structure. The output of this situation is representing in the development of a specific development concept of a rural settlement system - enhancing in agricultural production, creating the co-operative farms and their specialization based on local conditions [8].

However, the rural settlements network reduction is not always associated with a rural population decrease. Increasing the number of large rural settlements influenced by a 
variety of factors: transformation of the urban settlements into the rural ones and migration from medium and small villages. This has led to the rural population concentration in large settlements with the development potential, and to the formation of a new settlement framework of rural settlement [9].

Thus, today the Russian rural settlement system is located at the bifurcation point. In this regard, various development ways are possible for this system based on a variety of factors, both external and internal. Therefore, the study of forecast development options and optimization ways of rural settlement system seems particularly relevant today.

\section{Le Corbusier settlement system}

Le Corbusier settlement system includes three forms of settlement (Figure 1) [10]: Residential unit of agricultural production (food); Linear industrial city (production); Radial-ring city of social life (government, science, trade).

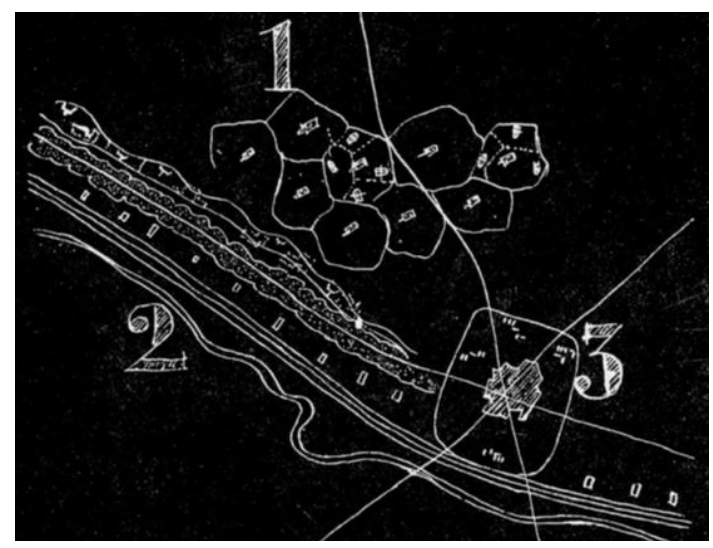

Fig. 2. The three forms of settlement of Le Corbusier: 1. Residential unit of agricultural production. 2. Linear industrial city. 3. Radial-ring city of social life.

We will consider the agricultural production unit.

Countryside unit. A rural unit management is carrying out by the mayor or by another administrator. A rural unit size exceeds the ordinary village size. Transport infrastructure must solve the needs of the agricultural production and cooperative center (Figure 3).

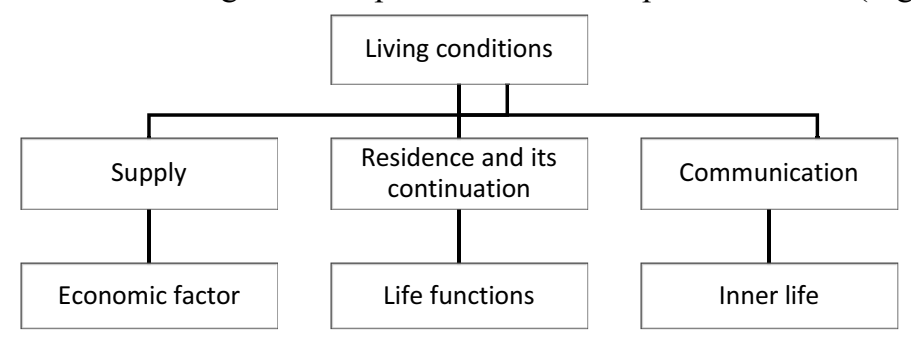

Fig. 3. The needs of agricultural production and cooperative centre.

The constituent parts of agriculture include cattle and the pastures, cattle yards and their equipment, feed storage, silage storage and feed kitchen, shepherds houses.

The cooperative center objects are dairy farm, agricultural products storage, mechanical workshops, a garage for agricultural machinery and motor vehicles, local enterprise for agricultural products processing; in addition, houses, cooperative store, school, youth 
workshops and social club with a sports complex.

Le Corbusier offers three options for cooperative centers. A. Rural Cooperative Center for a sufficiently large village; $\boldsymbol{B}$. Cooperative United Center for a number of nearby villages; $\boldsymbol{C}$. Cooperative center for a new agricultural production unit. The first two are composed of similar elements grouped into a single building "Cooperative Center" - a unified complex, headed by the leader, well positioned, well organized and maintained. Thus, there is a villages regrouping around a cooperative center.

Le Corbusier proposed two hypotheses. According to the first hypothesis, the rural unit with optimally short distances is in close proximity to the cultivated land, and the initiative of agricultural labor moves from the individual farmer to the group. This hypothesis is suitable for co-operative center serving the several nearby villages (B). The second hypothesis is basing on the organization of the cooperative land cultivation. The cooperative center may be located outside the settlements, while serving several villages. The transport infrastructure has to be well develop in this case.

To reduce the rural population outflow requires the following. 1) Creation the opportunity for satisfying the increased needs, while remaining to live and work in their village; 2) Creation the favorable living conditions; 3) Establishment a sufficient number of labor application places in the villages; 4) Provision food possibility by qualitative farm produce. The most important of the above seems in ensuring the of population employment, i.e. enhancing productive capacity. The presence of a permanent industry, where the rural population is engaging in throughout the year, can be barrier on a way of peasants escape from countryside.

Thus, the Co-operative Centre should be considering as a mechanism for bringing provision and welfare to the rural population. Thus, the farmer continuing to live and work in his usual rural surroundings can enjoy the advantages and achievements of a modern civilization.

The cooperative village. The elements of the cooperative village ("Radiant village") include the following. 1. Club. Youth House. The club is the real administrative and educational complex, community center of the commune. 2. Communal syndicate. Cooperative warehouse. The cooperative communal warehouse owned by an agricultural cooperative. His presence is a guarantee of security of the village and the country. 3. Cooperative Production Company. Companies of this kind should be placing directly in the village to meet the ever-increasing rural population requirements. 4. Cooperative allocator. It serves to organizing supply the essentials, food, dry goods, clothing, manufactured goods, and so on through the establishment of commercial enterprises. 5. Residence. The cooperative village is located away from large highways, near local roads. Therefore, all houses are located at the distance from the transport arteries. 6. Farm. It is proposing a uniform land distribution in farms.

Comparing reviewed settlement system, it is possible point out the following.

1. In Belarus, the support system of rural settlement network consists of agro-towns, evenly distributed across the country. The main objects of the socio-economic and industrial infrastructure, available for residents of nearby settlements, are concentrated in agro-towns. The current settlement system formed in the Soviet period and was further developing in the post-Soviet years. The majority of rural settlements belongs to agricultural activity type. This is due to the agrarian orientation of the state's economy.

2. The distribution unevenness and settlement types' variety, formed under the influence of agro-climatic conditions and economic demands, is a characteristic feature of the Russian agricultural settlement system. The system of rural settlement in Russia's regions has its own features, which complicates carrying out of a uniform policy.

Agricultural Reforms of the 1990s contributed to the settlement system transformation: - Transformation of the state and collective farms into joint stock companies, partnerships, 
cooperatives, etc.; - State lands monopoly cancellation and transfer it to small private landowners by dividing a large part of state-owned land used by agricultural enterprises on the land shares and permits for buying and selling of lands; - Creation the conditions for the farms and private households development; $\bullet$ Large agribusiness corporations' development.

3. Le Corbusier's settlement system based on optimal conditions' creation for agriculture. The ideal is a "Cooperative Village". It performs the functions of agroindustrial and socio-cultural center of the rural settlement system, which contributes to the inter-settlement connections' development.

Thus, the greatest similarity seems in Belarus rural settlement systems, and the "ideal" Le Corbusier's system. That suggests the correctly chosen development direction of Belarus rural settlement system. Considering the similarity of Belarus territorial division's scheme with a territorial structure in Russia, is possible to talk about the feasibility of using the experience of Belarus under Russian conditions.

\section{References}

1. O.V. Usol'ceva, Vestnik Tomskogo gosudarstvennogo universiteta, 397, 178-186 (2015)

2. V.V. Vladimirov, Problemy razvitija teorii rasselenija Rossii. (2003)

3. V.Ja. Ljubovnyj, Ju.A. Sdobnov, Sbornik materialov po problemam razvitija gorodskih aglomeracij $\mathrm{v}$ stranah SNG k nauchno-prakticheskoj konferencii «Nauchnye i prakticheskie aspekty formirovanija gorodskih aglomeracij», 13-24, (2011)

4. Nacional'nyj statisticheskij komitet respubliki Belarus' http://www.belstat.gov.by/ofitsialnaya-statistika/ssrd-mvf_2/natsionalnaya-stranitsasvodnyh-dannyh/chislennost-naseleniya-na-1-yanvarya-po-oblastyam-respublikibelarus/

5. Gosudarstvennaja shema kompleksnoj territorial'noj organizacii Respubliki Belarus (2007)

6. Gosudarstvennaja programma ustojchivogo razvitija sela na 2011-2015 gody, (2012)

7. P. N. Davidenko, E. V. Gorbenkova, Gradostroitel'stvo 5 (39), 37-70, (2015)

8. N.V. Chugunova, Ju.V. Litovchenko, S.A. Ignatenko, Geografija i region. Materialy mezhdunarodnoj nauchno-prakticheskoj konferencii, 283-288, (2015)

9. R.A. Galin, Jekonomika i upravlenie 5(127), 28-33 (2015)

10. Le Corbusier, Les éditions de minuit, Paris, (1959) 